\title{
FDA Approved Drugs and Herbal Based Inhibitors Target SARS CoV-2 RNA Dependent RNA Polymerase
}

\author{
Architha Vijayalakshmi ${ }^{1}$, Hemalatha Srinivasan 1,* (D) \\ 1 School of Life Sciences, B. S. Abdur Rahman Crescent Institute of Science and Technology, Vandalur, India \\ * Correspondence: hemalatha.sls@bsauniv.ac.in (H.S.);
}

Scopus Author ID 56895829300

Received: 3.05.2021; Revised: 5.07.2021; Accepted: 8.07.2021; Published: 11.09.2021

\begin{abstract}
The recent outburst of COVID-19 started as an epidemic in Wuhan city, China, in December 2019. It was declared a pandemic by World Health Organization on 30 January 2020. The rapid spread of the novel coronavirus leads to more deaths worldwide. Also, it has spared many lives in its second wave of disease in many countries. Although scientists had produced vaccines, it does not suit every human being, and they are getting infected again, which is due to a lack of extensive clinical trials. Also, drug repurposing is ineffective. There is a need for more research; using in silico methods may be the better option in the current situation to save the lives of virus-affected individuals. The drugs used for other diseases and herbal compounds might help target the coronavirus. In this study, a protein, RNA-dependent RNA polymerase (RdRp), was chosen as a target from the virus for molecular docking. It was docked against several drugs on the market and also several herbal compounds. This study will help further in vitro and in vivo studies with new lead compounds, new horizons for drugs in trials, and a new approach for Insilco analysis to treat COVID-19.
\end{abstract}

Keywords: COVID-19; drug repurposing; herbal compounds; RNA dependent RNA polymerase; molecular docking.

(c) 2021 by the authors. This article is an open-access article distributed under the terms and conditions of the Creative Commons Attribution (CC BY) license (https://creativecommons.org/licenses/by/4.0/).

\section{Introduction}

Coronavirus, in general, belongs to the Coronaviridae family and the sub-family of Coronavirinae [1]. It is an enveloped RNA virus which is positively stranded. The name corona arrived due to the halo-like appearance, which is the spikes of glycoproteins protruding from the envelope on the surface [1]. The recently bloomed virus in December 2019 causes fever, cough, shortness of breath, and tiredness. It leads to death for people with medical complications and people who are immunocompetent. Also, the second wave of the disease is leading to inflammatory diseases in humans. It has been raised as a threat to global health.

SARS CoV-2 was officially named COVID-19 by the World Health Organization. The SARS CoV-2 is related to SARS and MERS. In 2003, there was an outbreak of SARS in Hong Kong [2], which also spared many lives.

From the family of all known RNA viruses, the virus with a massive genome is the coronavirus. Its genome length is from 27-32 kilobase pairs [3], which is unknown in other RNA viruses. In this large genome, there are many proteins that help the virus inside the host, and also, there is much research carried out to inhibit it [4-6]. Still, a protein called RNAdependent RNA polymerase acts as the main key that helps the viral genome for the transcription in not only SARS CoV-2 but also all the RNA viruses. Thus for this study, RNAdependent RNA polymerase from SARS CoV-2 was chosen as a target. When this is being 
inhibited, the further spread of the virus inside the human cell can be stopped leading to a cure for the disease.

There have been many antiviral drugs for many viral diseases found [7]. Also, some drugs like Remdesivir and Chloroquine were checked for their effectiveness against SARSCoV-2 [8]. Remdesivir alone has proved its antiviral activity against many RNA viruses which has infected both humans and animals, such as Ebola, Nipah, SARS, and MERS [9]. Drugs and natural compounds from plants have shown their effectiveness against viral diseases [10-13]. Also, the natural compounds from plants have shown good responses against pneumonia-like infections [14]. And also, these herbal compounds can be made as nanocolloids [15-18] and nanoparticles for their even more effective application as a drug; these have been proved to be effective against various diseases in humans [19-22]. It is also less toxic in nosocomial infections[23,24]. Not only herbal compounds even nanoparticles from the fungal source have shown great applications in diseases [25-28]. For this study, nine drugs were selected for the docking purpose to inhibit the RdRp (Table 1). The selected drugs are FDA-approved. All these drugs have several activities and have been used to treat other viral infections. Apart from drugs, the compounds from herbs used in traditional Indian medicine were also selected. Eight compounds were selected to dock against the target (Table 2). These compounds also have many activities such as antiviral, anti-inflammatory, and also used for cancer.

In these years, the role of bioinformatics has tremendously increased. It has joined hands with pharmacology in developing drugs quickly with almost low risk $[33,34]$. The present study will explain the best inhibition drug or herbal compound of SARS CoV-2 using molecular docking. Additionally, there has been no known analysis of certain drugs and compounds from herbs in this study. The findings from this study will give the researchers a good idea in developing a more effective drug to fight against COVID-19. Apart from helping treat the coronavirus, the herbal compounds may also help find a cure for other diseases as they have been proven to be effective [29-32] and in use from the past centuries.

Table 1. FDA-approved drugs used for docking against RdRp in SARS CoV-2.

\begin{tabular}{|c|c|c|c|}
\hline No & Drug & Structure & Pharmacological function \\
\hline 1. & Ribavirin & & Treatment of HSV and HCV \\
\hline 2. & Sofosbuvir & & Treatment of Hepatitis C \\
\hline 3. & Oseltamivir & & Treatment of Influenza A \& B \\
\hline
\end{tabular}




\begin{tabular}{|c|c|c|c|}
\hline No & Drug & Structure & Pharmacological function \\
\hline 4. & Remdesivir & & $\begin{array}{l}\text { Treatment of EBOLA, Known to } \\
\text { inhibit viral RNA polymerase }\end{array}$ \\
\hline 5. & Zindovudine & & Treatment of HIV \&AIDS \\
\hline 6. & Favipiravir & & Treatment of influenza \\
\hline 7. & Umifenovir & & $\begin{array}{l}\text { Treatment of Influenza and other } \\
\text { Respiratory infections }\end{array}$ \\
\hline 8. & Triazavirin & & Treatment of Influenza A \& B \\
\hline 9. & Galidesivir & & Treatment of Zaire EBOLA virus \\
\hline
\end{tabular}

Table 2. Compounds from herbs used for docking against RdRp in SARS CoV-2.

\begin{tabular}{|c|c|c|c|c|c|}
\hline \multirow[t]{2}{*}{ No } & \multirow{2}{*}{$\begin{array}{c}\text { Compound } \\
\text { name }\end{array}$} & \multirow[t]{2}{*}{ Structure } & \multirow[t]{2}{*}{ Known Function } & \multicolumn{2}{|c|}{ Source } \\
\hline & & & & Common name & Scientific name \\
\hline 1. & Carvacrol & & $\begin{array}{c}\text { Anti-bacterial } \\
\text { Anti-fungal } \\
\text { Boost immune system }\end{array}$ & Oregano & Origanumvulgare \\
\hline 2. & Safficinocide & & Anti-viral & Sage & Salvia officinalis \\
\hline
\end{tabular}




\begin{tabular}{|c|c|c|c|c|c|}
\hline \multirow[t]{2}{*}{ No } & \multirow{2}{*}{$\begin{array}{c}\text { Compound } \\
\text { name }\end{array}$} & \multirow[t]{2}{*}{ Structure } & \multirow[t]{2}{*}{ Known Function } & \multicolumn{2}{|c|}{ Source } \\
\hline & & & & Common name & Scientific name \\
\hline 3. & Ursolic acid & & Anti-inflammatory & Holy basil & Ocimumtenuiflorum \\
\hline 4. & Trans anethole & & Anti-inflammatory & Fennel & Foeniculumvulgare \\
\hline 5. & Allicin & & $\begin{array}{l}\text { Anti-bacterial } \\
\text { Anti-fungal }\end{array}$ & Garlic & Allium sativum \\
\hline 6. & Glabridin & & Anti plasmodial drug & Licorice & Glycyrrhizaglabra \\
\hline 7. & Gingerols & & Antineoplastic agent & Ginger & Zingiberofficinale \\
\hline
\end{tabular}

\section{Materials and Methods}

\subsection{Databases and software used.}

Databases: Protein data bank, Drug Bank, PubChem.

Software: Auto dock 4, Biovia Discovery Studio, Open Babel, Pymol.

\subsection{COVID-19 RdRp structure.}

The RNA-dependent RNA polymerase was selected as a target from the virus. The protein 3-dimensional structure was downloaded from the Research Collaboratory for Structural Bioinformatics website (RCSB) https://www.rcsb.org/. The protein was downloaded in PDB format for docking purposes. 


\subsection{Drug as ligand preparation.}

In this study, the drugs already approved by the FDA and the drugs currently in the study were taken. The 3-dimensional structure for the ligand was downloaded from the Drug bank website https://www.drugbank.ca/. The drugs were downloaded in PDB format.

\subsection{Compounds from herbs as ligand preparation.}

The main component from herbal plants used in early Indian and Chinese medicine was selected. The compounds were downloaded from the PubChem website https://pubchem.ncbi.nlm.nih.gov/. The compounds were downloaded in SDF format. It was then converted to PDB format by using the Open Babel software http://openbabel.org/wiki/Main_Page.

\subsection{Molecular docking.}

The ligands were docked against the protein to find out the best inhibitor for RdRp in SARS CoV-2. The docking procedure was carried out by using Auto dock 4 software http://autodock.scripps.edu/.

\subsection{Analyzing the result.}

The analysis of the docking was done in Discovery studio software https://discover.3ds.com/. The interacting amino acids with the target protein were all found. The binding energy was also found to find the best inhibiting molecule. The docking pose of the best inhibiting molecule for drug and the herbal compound was done using Pymol software https://pymol.org/2/.

\section{Results and Discussion}

The currently emerged virus is creating a catastrophic situation for the whole world. This will be stopped only when a cure is found. Finding a vaccine or drug can be more timeconsuming; thus bioinformatics method of analysis will be of great use for not only fully eradicating but can be stopped to an extent. As soon as the virus rose up in China, researchers worldwide started to sequence the virus's genome. The protein RdRp was first made online Protein Data Bank website in April 2020. The discovery of this protein structure in the virus provided a good opportunity to identify drugs and compounds, especially for Insilico analysis to combat the virus.

Already it is evident that herbal compounds showed good efforts in treating viral diseases in humans $[35,36]$. Many drugs have also exhibited good antiviral efforts in humans $[7,8]$. Today's world of research has grown to greater heights; it has successfully served mankind curing a wide range of diseases, including deadly cancer and neuro diseases [37-40]. In this study, using molecular docking studies, nine drugs in which some have been approved and seven herbal compounds were explored for their inhibitory effect on RdRp in COVID-19.

The docking result for the ligand and protein was determined by the binding energy produced. Their molecular formula, binding energy, and interacting amino acid are shown (Table 3). All the herbal compounds used their molecular formula, herbal source, binding energy, and interacting amino acid are shown (Table 4). 
Table 3. Molecular docking of drugs against RdRp in COVID-19.

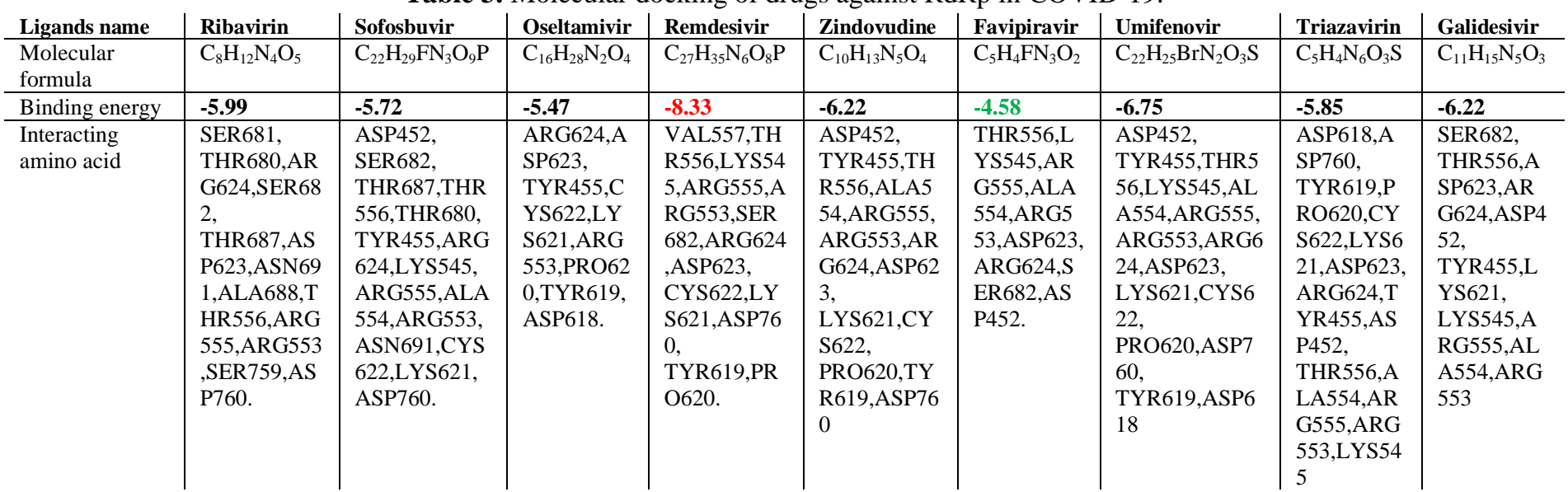

The result based on the binding energy value for the drugs as ligands docked were Remdesivir $>$ Umifenovir $>$ Zindovudine $>$ Galidesivir $>$ Ribavirin $>$ Triazavirin $>$ Sofosbuvir $>$ Oselt amivir $>$ Favipiravir. The binding energies were $-8.33,-6.75,-6.22,-6.22,-5.99,-5.85,-5.72,-$ 5.47 and -4.58 respectively. The results for the herbal compounds as ligands docked were Ursolic acid $>$ Glabridin $>$ Safficinolide $>$ Allicin $>$ Carvacrol $>$ Trans anethole $>$ Gingerols. The binding energies were $-10.88,-7.78,-7.39,-5.67,-5.15,-4.63,-4.56$ respectively. The docking pose of all the ligands with the RdRp protein is shown (Figure 1).

Table 4. Molecular docking result of herbal compounds against RdRp in COVID-19.

\begin{tabular}{|c|c|c|c|c|c|c|c|}
\hline Ligand Name & Carvacrol & Safficinolide & $\begin{array}{l}\text { Ursolic } \\
\text { acid }\end{array}$ & $\begin{array}{l}\text { Trans } \\
\text { anethole }\end{array}$ & Allicin & Glabridin & Gingerols \\
\hline Molecular formula & $\mathrm{C}_{10} \mathrm{H}_{14} \mathrm{O}$ & $\mathrm{C}_{20} \mathrm{H}_{24} \mathrm{O}_{5}$ & $\mathrm{C}_{30} \mathrm{H}_{48} \mathrm{O}_{3}$ & $\mathrm{C}_{10} \mathrm{H}_{12} \mathrm{O}$ & $\mathrm{C}_{6} \mathrm{H}_{10} \mathrm{OS}_{2}$ & $\mathrm{C}_{20} \mathrm{H}_{20} \mathrm{O}_{4}$ & $\mathrm{C}_{17} \mathrm{H}_{26} \mathrm{O}_{4}$ \\
\hline Herbal source & Oregano & Sage & Holy Basil & Fennel & Garlic & Licorice & Ginger \\
\hline Binding energy & -5.15 & -7.39 & -10.88 & -4.63 & -5.67 & -7.78 & -4.56 \\
\hline Interacting Amino Acid & $\begin{array}{l}\text { SER681, } \\
\text { THR680, } \\
\text { ARG624, } \\
\text { ASP623, } \\
\text { SER682, } \\
\text { THR556, } \\
\text { ALA558, } \\
\text { MET542, } \\
\text { TYR456, } \\
\text { LYS676. }\end{array}$ & $\begin{array}{l}\text { ARG624, } \\
\text { ASP623, } \\
\text { CYS622, } \\
\text { LYS621, } \\
\text { ASP760, } \\
\text { TYR619, } \\
\text { ARG553. }\end{array}$ & $\begin{array}{l}\text { TYR455, } \\
\text { ASP452, } \\
\text { THR556, } \\
\text { ARG62, } \\
\text { ASP623, } \\
\text { LYS621, } \\
\text { CYS622, } \\
\text { PRO620, } \\
\text { TYR619, } \\
\text { ALA554, } \\
\text { ARG55. }\end{array}$ & $\begin{array}{l}\text { LYS676, } \\
\text { TYR456, } \\
\text { MET54, } \\
\text { ARG62, } \\
\text { THR680, } \\
\text { SER681, } \\
\text { ASP623, } \\
\text { ALA55, } \\
\text { THR556, } \\
\text { SER682. }\end{array}$ & $\begin{array}{l}\text { PRO461, } \\
\text { MET463, } \\
\text { THR462, } \\
\text { THR246, } \\
\text { LEU460, } \\
\text { ASN791, } \\
\text { LEU247, } \\
\text { PRO243, } \\
\text { TYR788. }\end{array}$ & $\begin{array}{l}\text { ARG624, } \\
\text { ASP623, } \\
\text { TYR455, } \\
\text { SER682, } \\
\text { VAL557, } \\
\text { ASP452, } \\
\text { THR556, } \\
\text { ARG555, } \\
\text { LYS545, } \\
\text { ARG553. }\end{array}$ & $\begin{array}{l}\text { LYS676, } \\
\text { TYR456, } \\
\text { THR680, } \\
\text { ARG624, } \\
\text { ASP623, } \\
\text { SER681, } \\
\text { SER682, } \\
\text { ALA558, } \\
\text { MET542, } \\
\text { VAL557, } \\
\text { THR556, } \\
\text { ARG555, } \\
\text { LYS545, } \\
\text { ARFG553 }\end{array}$ \\
\hline
\end{tabular}

The information mentioned above shows us that in the case of drugs as a cure for COVID-19, the drugs Remdesivir, Umifenovir, Zidovudine, and Galidesivir showed good binding energy and were found to be very effective against RdRp. And in the case of herbal compounds Ursolicacid, Glabridin, and Safficinolide, binding energies depict the very good interaction with the target protein RdRp. According to this study, the docking pose of the bestdocked drug and herbal compound to protein is also shown (Figure 2). From this study, it is recommended to use Remdesivir as a drug and as Ursolic acid-containing Holy Basil as a dietary supplement.

Table 4 shows the molecular docking result of herbal compounds with their molecular formula, herbal source, binding energy, and interacting amino acid. The binding energy indicated in red color shows the highest energy, and the green color shows the lowest. 
Remdesvir

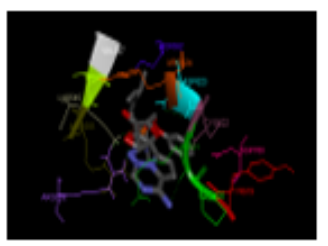

Ribavirin

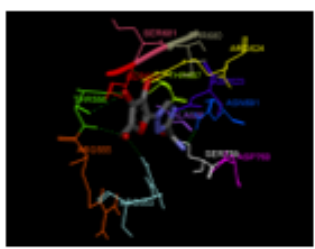

Favipiravir

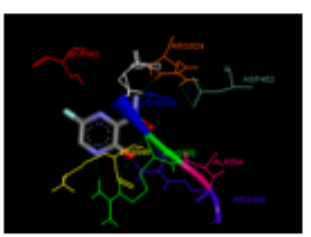

Allicin

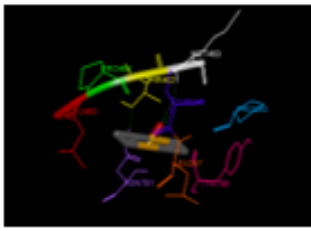

Umifenovir

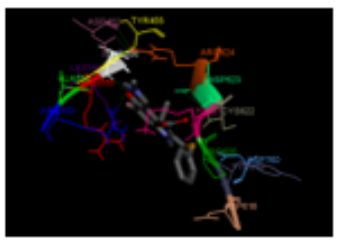

Triazavirin

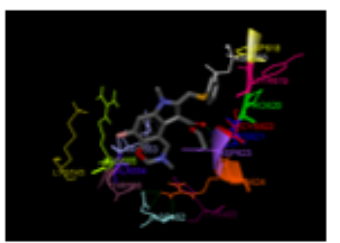

Ursolic acid

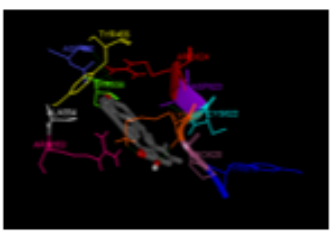

Carvacrol

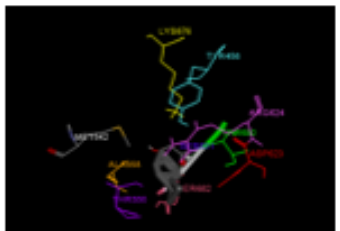

Zindovudine

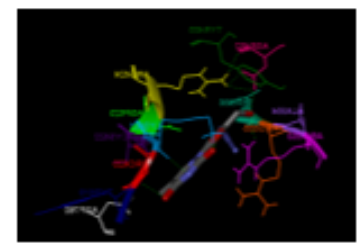

Sofosbuvir

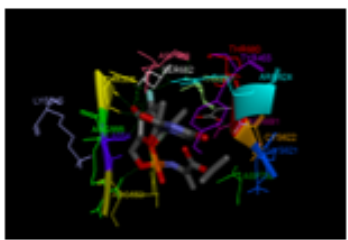

Glabridin

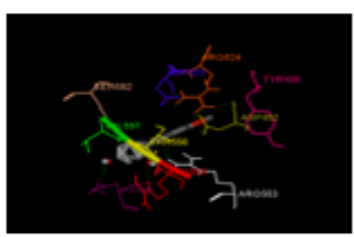

Trans anethole

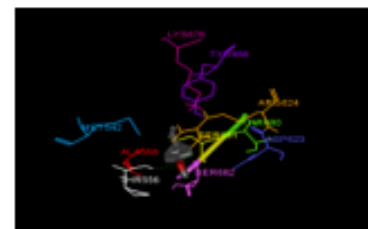

Galidesivir

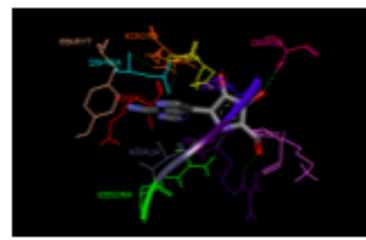

Oseltamivir

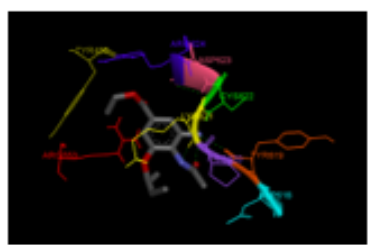

Saffocinolide

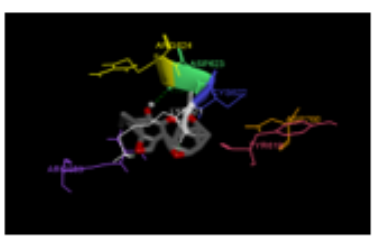

Gingerols

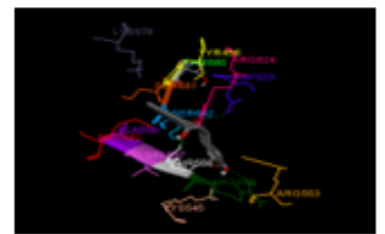

Figure 1. Docking pose of all the ligands with the protein using Biovia Discovery Studio.

This figure shows the docking pose of all the ligands with the protein using Biovia discovery studio. In figure 1, yellow-colored inlet captions depict the drugs, and green colored inlet captions depict the herbal compounds.

\section{Ribavirin}

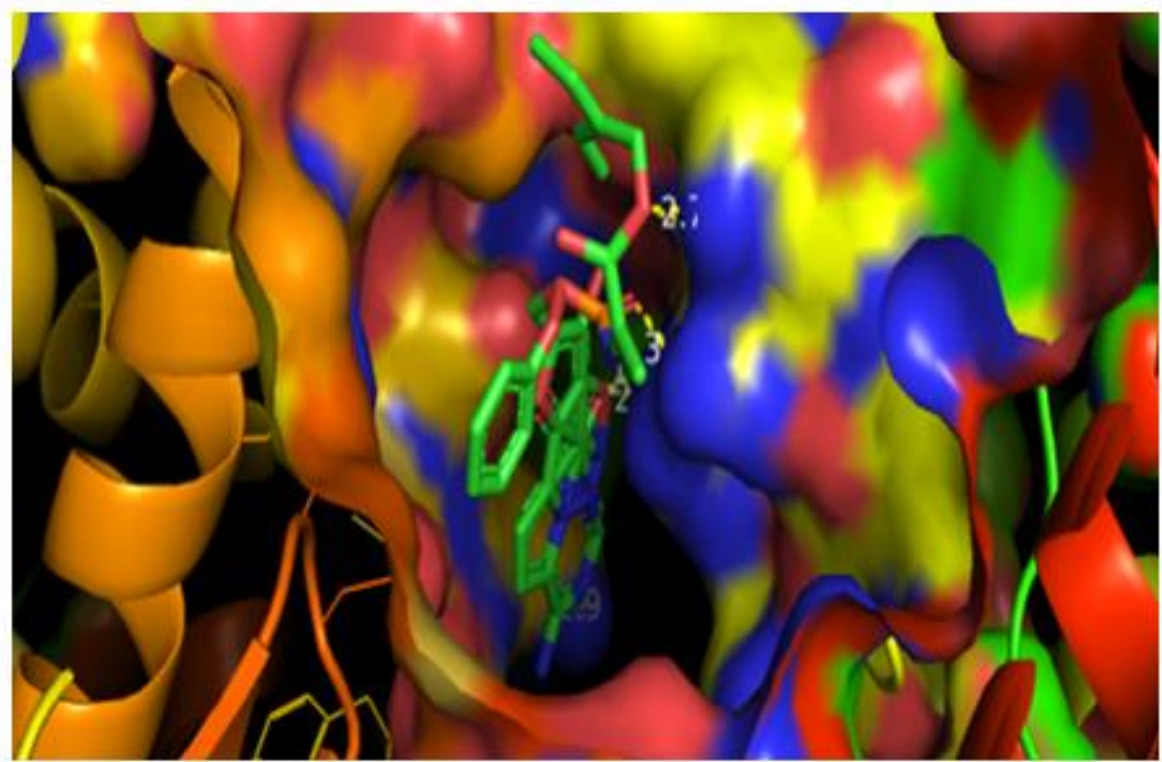




\section{Ursolic acid}

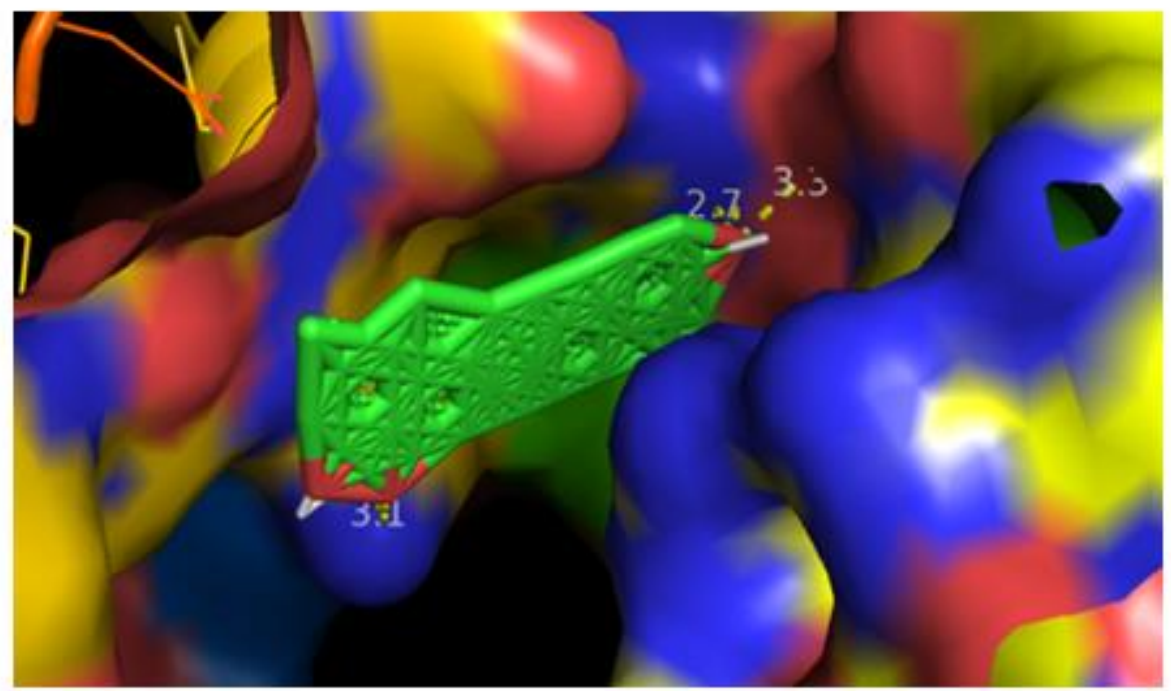

Figure 2. Docking pose of best-docked ligands (Ribavirin and UrsolicAcid) using Pymol.

This figure shows the best-docked ligand with the protein Ribavirin and Ursolic Acid.

\section{Conclusions}

Currently, the coronavirus has become a great health topic due to its worst ongoing second wave worldwide. Many covid infections have created life threats causing the deaths of lakhs of human beings. This worsening COVID pandemic has raised the development of effective antiviral agents from herbal sources to prevent further losses. Herbal compounds have played a great role in developing a drug against this pandemic, causing COVID and other diseases. Also, repurposing of drugs available had been more helpful to save patients diagnosed with early infection leading to a reduction in the death rate of affected people. This study's main aim was to identify herbal compounds and repurposing drugs to combat the COVID-19. And from this study, it was found that Ursolic acid is effective against COVID 19 through targeting RdRp. This study will provide a platform for the researchers to find a cure through drug development and eradicate the virus out from this world.

\section{Funding}

The current research is funded by the Ministry of Science and Technology, Department of Science and Technology (DST/SATYAM/COVID-19/2020/213 (G)).

\section{Acknowledgments}

The author is thankful to B.S. Abdur Rahman Institute of Science \& Technology, Chennai, provides research facilities in the School of Life Sciences. The authors also gratefully acknowledge the Ministry of Science and Technology, Department of Science and Technology DST/SATYAM/COVID-19/2020/213 (G) for funding.

\section{Conflicts of Interest}

The authors declare no conflict of interest. 


\section{References}

1. Adachi, S.; Koma,T.; Doi, N.; Nomaguchi, M.; Adachi, A. Commentary: Origin and evolution of pathogenic corona viruses. Frontiers in immunology 2020, 11, https://doi.org/10.3389/fimmu.2020.00811.

2. Mandala, V.S.; McKay, M.J.; Shcherbakov, A.A.; Dregni, A.J.; Kolocouris, A.; Hong, M. Structure and Drug Binding of the SARS-CoV-2 Envelope Protein in Phospho lipid Bilayers. Research square 2020, rs.3.rs77124, https://doi.org/10.21203/rs.3.rs-77124/v1.

3. Lee, N.; Hui, D.; Wu, A.; Chan, P.; Cameron, P.; Joynt, G.M.; Ahuja, A.; Yung, M.Y.; Leung, C.B.; To, K.F.; Lui, S.F.; Szeto, C.C.; Chung, S.; Sung, J.J.Y.A Major Outbreak of Severe Acute Respiratory Syndrome in Hong Kong. New England Journal of Medicine 2003, 348, 1986-1994, https://doi.org/10.1056/NEJMoa030685.

4. Shah, B.; Modi, P.; Sagar, S.R. In silico studies on therapeutic agents for COVID-19: Drug repurposing approach. Life Sciences 2020, 252, https://doi.org/10.1016/j.lfs.2020.117652.

5. Vincent, S.; Arokiyaraj, S.; Saravanan, M.; Dhanraj, M. Molecular Docking Studies on the Anti-viral Effects of Compounds From Kabasura Kudineer on SARS-CoV-23CL ${ }^{\text {pro }}$. Frontiers in molecular biosciences 2020, 7, https://doi.org/10.3389/fmolb.2020.613401.

6. Rolta, R.; Yadav, R.; Salaria, D.; Trivedi, S.; Imran, M.; Sourirajan, A.; Baumler, D.J.; Dev,K. In silico screening of hundred phytocompounds of ten medicinal plants as potential inhibitors of nucleocapsid phosphoprotein of COVID-19: an approach to preven tvirus assembly. Journal of biomolecular structure \& dynamics 2020, 1-18, https://doi.org/10.1080/07391102.2020.1804457.

7. Gross, A.E.; Bryson, M.L. Oral Ribavirin for the Treatment of Noninfluenza Respiratory Viral Infections: A Systematic Review. The Annals of pharmacotherapy 2015, 49, 1125-1135, https://doi.org/10.1177/1060028015597449.

8. Wang, M.; Cao, R.; Zhang, L.; Yang, X.; Liu, J.; Xu, M.; Shi, Z.; Hu, Z.; Zhong,W.; Xiao,G. Remdesivir and chloroquine effectively inhibit the recently emerged novel coronavirus (2019-nCoV) invitro. Cell research 2020, 30, 269-271, https://doi.org/10.1038/s41422-020-0282-0.

9. Sheahan, T.P.; Sims, A.C.; Graham, R.L.; Menachery, V.D.; Gralinski, L.E.; Case, J.B.; Leist, S.R.; Pyrc, K.; Feng, J.Y.; Trantcheva, I.; Bannister, R.; Park, Y.; Babusis, D.; Clarke, M.O.; Mackman, R.L.; Spahn, J.E.; Palmiotti, C.A.; Siegel, D.; Ray, A.S.; Cihlar, T.; Baric, R.S. Broad-spectrum antiviral GS-5734 inhibits both epidemic and zoonotic coronaviruses. Science translational medicine 2017, 9, https://doi.org/10.1126/scitranslmed.aal3653.

10. Chiang, L.C.; Chiang, W.; Chang, M.Y.; Ng, L.T.; Lin, C.C. Antiviral activity of Plant ago major extracts and related compounds invitro. Antiviral research 2002, 55, 53-62, https://doi.org/10.1016/s01663542(02)00007-4.

11. Lim, H.J.; Nguyen, T.T.; Kim, N.M.; Park, J.S.; Jang, T.S.; Kim, D. Inhibitory effect of flavonoids against NS2B-NS3 protease of ZIKA virus and their structure activity relationship. Biotechnology letters 2017, 39, 415-421, https://doi.org/10.1007/s10529-016-2261-6.

12. Park, S.W.; Kwon, M.J.; Yoo, J.Y.; Choi, H.J.; Ahn, Y.J. Antiviral activity and possible mode of action of ellagic acid identified in Lagerstroemia speciosa leaves toward human rhino viruses. BMC complementary and alternative medicine 2014, 14, https://doi.org/10.1186/1472-6882-14-171.

13. Nahmias, Y.; Gold wasser, J.; Casali, M.; vanPoll, D.; Wakita, T.; Chung, R.T.; Yarmush, M.L. Apolipo proteinB-dependent hepatitis $\mathrm{C}$ virus secretion is inhibited by the grape fruit flavonoid naringenin. Hepatology (Baltimore,Md.) 2008, 47, 1437-1445, https://doi.org/10.1002/hep. 22197.

14. Sah, S.K.; Rasool, U.; Hemalatha, S. Andrographi spaniculata extract inhibit growth, biofilm formation in multi drug resistant strains of Klebsiella pneumoniae. Journal of traditiona land complementary medicine 2019, 10, 599-604, https://doi.org/10.1016/j.jtcme.2019.02.006.

15. Ranjani, S.; Pradeep, P.; Vimal kumar, U.; Ramesh Kumar, V.; Hemalatha, S. Pungent anti-infective nanocolloids manipulate growth, biofilm formation, and CTX-M-15 gene expression in pathogens causing vibriosis. Aquaculture International 2021, 29, 859-869, https://doi.org/10.1007/s10499-021-00660-2.

16. Soundhararajan, R.; Mohamed Sheik Meeran, S.; Prakash, S. P.; Mohammad, W.; Kandasamy, R.; Srinivasan, H. Multipotent aromatic nanocolloid: synthesis, characterization and applications. AMB Express 2020, 10, https://doi.org/10.1186/s13568-020-01104-5.

17. Ranjani, S.; Tamanna, K.; Hemalatha, S. Triphala green nanocolloids: synthesis, characterization and screening biomarkers. Appl Nanosci 2020, 10, 1269-1279, https://doi.org/10.1007/s13204-019-01208-w.

18. Ranjani, S.; Shariq Ahmed, M.; Ruckmani, K.; Hemalatha, S. Green Nanocolloids Control Multi Drug Resistant Pathogenic Bacteria. Journal of Cluster Science 2020, 31, 861-866, https://doi.org/10.1007/s10876019-01694-6.

19. Akther, T.; Khan, M.S.; S, H. Biosynthesis of silver nanoparticles via fungal cell filtrate and their anti-quorum sensing against Pseudomonas aeruginosa. Journal of Environmental Chemical Engineering 2020, 8 , https://doi.org/10.1016/j.jece.2020.104365.

20. Ranjani, S.; Faridha Begum, I.; Santhoshini, J.; Senthil Kumar, N.; Ruckmani, K.; Hemalatha S. Mimosa pudica floral nanoparticles: a potent antibiotic resistance breaker. Inorganic and Nano-Metal Chemistry 2020, 1-8, https://doi.org/10.1080/24701556.2020.1852429. 
21. Sabiha Sulthana, H.B.; Ranjani, S.; Hemalatha, S. Comparison of efficacy of nanoparticles synthesized from leaves and flowers of Russelia equisitiformis. Inorganic and Nano-Metal Chemistry 2020, 1-9, https://doi.org/10.1080/24701556.2020.1862218.

22. Sai Nivetha, S.; Ranjani, S.; Hemalatha, S. Synthesis and application of silver nanoparticles using Cissus quadrangularis. Inorganic and Nano-Metal Chemistry $2020, \quad 1-8$, https://doi.org/10.1080/24701556.2020.1862219.

23. Ranjani, S.; Shariq Ahmed, M.; Mubarak Ali, D.; Ramachandran, C.; Senthil Kumar, N.; Hemalatha, S. Toxicity assessment of silver nanoparticles synthesized using endophytic fungi against nosacomial infection. Inorganic and Nano-Metal Chemistry 2021, 51, https://doi.org/10.1080/24701556.2020.1814332.

24. Shanmuga sundaram, P.; Saroj Kumar, S.; Ubaid, R.; Mahasampath Gowri, S.; Easwaramoorthy, D.; Hemalatha, S. Novel curcumin analogs act as antagonists to control nosocomial infection causing Pseudomonas aeruginosa. Biocatalysis and Agricultural Biotechnology 2019, 20, https://doi.org/10.1016/j.bcab.2019.101238.

25. Akther, T.; Vabeiryureilai, M.; Nachimuthu Senthil, K.; Davoodbasha, M.; Srinivasan, H. Fungal-mediated synthesis of pharmaceutically active silver nanoparticles and anticancer property against A549 cells through apoptosis. Environmental Science and Pollution Research 2019, 26, 1364913657,https://doi.org/10.1007/s11356-019-04718-w.

26. Shariq Ahmed, M.; Soundhararajan, R.; Akther, T.; Kashif, M.; Khan, J.; Waseem, M.; Srinivasan, H. Biogenic AgNPs synthesized via endophytic bacteria and its biological applications. Environmental Science and Pollution Research 2019, 26, 26939-26946, https://doi.org/10.1007/s11356-019-05869-6.

27. Ranjani, S.; Shariq Ahmed, M.; Mohd, A.; Senthil Kumar, N.; Ruckmani, K.; Hemalatha, S. Synthesis, characterization and applications of endophytic fungal nanoparticles. Inorganic and Nano-Metal Chemistry 2021, 51, 280-287, https://doi.org/10.1080/24701556.2020.1784231.

28. Ranjani, S.; Rumelee, D.; Shariq Ahmed, M.; Esther, L.; Senthil kumar, N.; Ruckmani, K.; Hemalatha, S. Myco-nanocolloids manipulate growth, biofilm formation and virulence genes in UTI causing E. coli. Inorganic and Nano-Metal Chemistry 2020, 1-10, https://doi.org/10.1080/24701556.2020.1852426.

29. Mittal, L.; Camarillo, I.G.; Varadarajan, G.S.; Srinivasan, H.; Aryal, U.K.; Sundararajan, R. High-throughput, Label-Free Quantitative Proteomic Studies of the Anticancer Effects of Electrical Pulses with Turmeric Silver Nanoparticles: an in vitro Model Study. Scientific Reports 2020, 10, https://doi.org/10.1038/s41598-02064128-8.

30. Preethi, B.; Saroj kumar, S.; Jayaprakash, R.; Kutti Rani, S.;Hemalatha, S. Synthesis, characterization and biological studies on 4-bromo-2-\{(z)-[(furan-2-ylmethyl) imino]methyl $\}$ phenol praseodymium complex Rasayan. J.Chem 2019, 12,1455-1462.

31. Rohini, B.; Tahira, A.; Waseem, M.; Khan, J.; Kashif, M.; Hemalatha, S. AgNPs from Nigella sativa control breast cancer: An In vitro study. Journal of Environmental Pathology, Toxicology and Oncology 2019, 38, 185-194, https://doi.org/10.1615/JEnvironPatholToxicolOncol.2019027318.

32. Venkatasubramanian, H.; Saroj kumar, S.; Hemalatha ,S.; Easwaramoorthy, D. Synthesis, characterisation and antimicrobial activity of new nicotinamide-thiazole derivatives. RJC 2020, 12 , https://doi.org/10.26452/ijrps.v11i2.2292.

33. Ortega, S.S.; Cara, L.C.; Salvador, M.K. Insilico pharmacology for a multidisciplinary drug discovery process. Drug metabolism and drug interactions 2012, 27, 199-207, https://doi.org/10.1515/dmdi-20120021.

34. Lutfiya, A.S.; Priya, S.; Manzoor, M.A.P.; Hemalatha, S. Molecular docking and interactions between vascular endothelial growth factor (VEGF) receptors and phytochemicals: An in-silico study. Biocatalysis and Agricultural Biotechnology 2019, 22, https://doi.org/10.1016/j.bcab.2019.101424.

35. Islam, M.T.; Sarkar, C.; El-Kersh, D.M.; Jamaddar, S.; Uddin, S.J.; Shilpi, J.A.; Mubarak, M.S. Natural products and their derivatives against coronavirus: A review of the non-clinical and pre-clinical data. Phytotherapy Research 2020, 34, 2471-2492, https://doi.org/10.1002/ptr.6700.

36. Matveeva, T.; Khafizova, G.; Sokornova, S. In Search of Herbal Anti-SARS-Cov2 Compounds. Frontiers in plant science 2020, 11, https://doi.org/10.3389/fpls.2020.589998.

37. Arpudhamary, V.; Priya, S.; Manzoor, M.A.P.; Mubarakali, D.; Hemalatha, S. Apoptotic-inducing factor 1 (AIF1) plays a critical role in cembranoid mediated apoptosis to control cancer: Molecular docking and dynamics study. Biocatalysis and Agricultural Biotechnology 2019, 22, https://doi.org/10.1016/j.bcab.2019.101343.

38. Hariharan, V.; Sha, S.; Srinivasan, H.; Deivanayagam, E. Synthesis, characterization of new nicotinamideoxazole analogs, and their antimicrobial activity. International Journal of Research in Pharmaceutical Sciences 2020, 11, 2707-2712, https://doi.org/10.26452/ijrps.v11i2.2292.

39. Basha, F.H.; Waseem, M.; Srinivasan, H. Cellular and molecular mechanism in neurodegeneration: Possible role of neuroprotectants. Cell Biochemistry and Function 2021, 39, 613-622, https://doi.org/10.1002/cbf.3630. 
40. Mariam Adhila, H.; Shariq Ahmed, M.; Ranjani, S.; Senthil kumar, N.; Hemalatha, S. Marine endophytic fungi mediated silver nanoparticles and their application in plant growth promotion in Vigna radiata.L Inter.J.Nano.Dimen 2020, 12, 1-10. 